\title{
Apresentação à entrevista com Jeanne Favre-Saada
}

\author{
autores: Melissa Moura Melo, Marco Antonio Saretta Poglia
}

A oportunidade de publicar a tradução desta entrevista representa mais um passo para a imersão no pensamento de uma autora cuja obra é ainda muito pouco conhecida no Brasil. Jeanne Favret-Saada é autora de uma proposta atraente para os seguidores da antropologia, embora sua abordagem questione o coração mesmo da disciplina. Na avaliação da etnóloga, todavia, a agudez de sua crítica não foi percebida por grande parte de seus leitores, ocorrendo o que Walter Benjamin chamou de uma "incompreensão entusiasta”.

Como observou o antropólogo Márcio Goldman, apesar de ser autora de ampla bibliografia, Favret-Saada faz parte daquele grupo de autores conhecidos por ter escrito um livro, Les Mots, la Mort, les Sorts: la sorcellerie dans le Bocage (1977), "uma das raras obras-primas da história do pensamento antropológico" (Goldman, 2005, p. 149). No Brasil, não nos parece forçoso afirmar que a etnóloga é mais conhecida por ter escrito um artigo: Ser Afetado, traduzido por Paula Siqueira e publicado na revista Cadernos de Campo, edição no 13 (2005). Isso em grande parte talvez porque, exceção feita ao pequeno e instigante ensaio que vem se fazendo cada vez mais presente nas referências bibliográficas nos últimos anos, sua obra não possui ainda tradução para a língua portuguesa.

Nesta entrevista, a autora tunisiana revela ainda aspectos de sua trajetória pessoal ("ser uma filha de judeus em uma sociedade misógina, colonial e racista") e as condições de seu trabalho como etnóloga. Não vendo nenhuma incompatibilidade entre assumir uma posição política e ser pesquisadora, a autora discorre sobre um tipo de "retroação perpétua entre um modo não-partidário de ser na política, e um modo náo-escolar de fazer pesquisa”. Um modo não escolar porque algumas condiçóes assim o exigiram. Seu primeiro trabalho de campo foi realizado na Argélia logo após a sua independência, em 1962, depois de ter vivido três anos naquele país sob guerra. De acordo com a etnóloga, "minha 'posição metodológica' teria sido a mais clássica possível se a situação também assim o fosse: a etnologia não tinha um método para estudar um país em plena revolução" (Favret-Saada, 2009, p. 2).

$\mathrm{O}$ mesmo se passou quando, alguns anos mais tarde, foi estudar a feitiçaria no Bocage: somente ao perceberem-na inscrita no sistema local de feitiçaria (seja como desenfeitiçadora, seja como enfeitiçada) é que os nativos se dispuseram a conversar com ela sobre o assunto. Não haveria outra escolha; foi preciso aceitar fazer parte de um "sistema de lugares" desconhecido e se deixar afetar pela alteridade. Da mesma forma quanto às questóes a serem levantadas: "Logo que comecei a trabalhar, meu primeiro princípio foi: já que ignoramos quais são as perguntas certas, comecemos por nos calar e compreender do que eles falam entre eles, quais são, para eles, as perguntas relevantes" (Favret-Saada, 2008, p. 4).

Estas foram as contingências que possibilitaram (ou infligiram) a Jeanne Favret-Saada elaborar sua teoria a partir da afetação recíproca. E para isso foi preciso estabelecer uma 
postura crítica à hierarquia entre a razão e o afeto presente na disciplina desde Durkheim, que situa sempre o outro na trágica esfera do irracional. Ora, segundo a autora, a experiência do irracional, do afetivo náo-representado, é intrínseca a toda experiência humana.

Favret-Saada rompe assim com qualquer pretensão de apreender um sistema de representaçóes nativo. "É isso o que me interessa na antropologia: o efeito bumerangue que produz inevitavelmente todo verdadeiro contato com o outro" (Favret-Saada, 2008, p. 90). A crítica a essa "epistemologia da distância" (Favret-Saada, 2009, p. 3) na antropologia posiciona-se assim contra a assimetria entre pesquisador e nativo, cujos pressupostos encontram-se enraizados no primado da representação. Está em jogo aqui a pressuposição de objetividade no trabalho etnográfico: é preciso apenas que estejamos abertos ao ponto de vista do outro e sejamos capazes de compreender algo a seu respeito.

Dentre todas as armadilhas que ameaçam nosso trabalho, existem duas das quais aprendemos a desconfiar da mesma forma que se desconfia da peste: aceitar participar do discurso do nativo e sucumbir às tentações da subjetividade. Além de não ter podido evitá-las, foi por meio delas que elaborei o essencial da minha etnografia (Favret-Saada, 1977, p. 38)

Psicanalista por mais de duas décadas, Favret-Saada discorre nesta entrevista sobre a influência deste saber em seu trabalho como etnóloga. A despossessão de si, a aceitação do desejo desconhecido do outro e o reconhecimento de uma opacidade constitutiva da comunicação humana - implicações de uma postura adotada em campo marcada pela abertura para o ponto de vista do outro - , "tudo isso era banal para os analistas, insuportável para os etnólogos”, afirma. Mas se esse aspecto possibilitou o apoio de alguns psicanalistas ao seu trabalho no momento em que os etnólogos dele se distanciavam - talvez porque a abordagem de Favret-Saada desestabilizava muitas das suas certezas -, a simetrização antropológica proposta pela etnóloga fez com que essa aliança não se estendesse por muito tempo. Ao afirmar que a psicanálise era uma forma de terapia entre outras, como o desenfeitiçamento, a pesquisadora viu-se frente ao fechamento total do meio analítico à sua "heresia teórica". O mesmo ocorreu mais tarde, quando tratou dos "afetos não-representados" e sua função de cura.

Favret-Saada comenta também sobre a importância da elaboração de um diário de campo enquanto consignação de uma experiência. Esse registro servirá mais tarde para o que a autora chama de "terceiro momento lógico" do trabalho etnográfico: a retomada dessa experiência para participar de um empreendimento de conhecimento. Isso pode ocorrer anos mais tarde, afirma, e é assim significativo observar que o seu Les Mots, la Mort, les Sorts tenha levado quase uma década para ser publicado, a contar do início de sua pesquisa.

A autora fala ainda sobre alguns dos objetos de estudo que constituem a sua obra. Jeanne Favret-Saada escreveu sobre a vingança cabila no século XIX, insurreições rurais na Argélia independente, a feitiçaria bocana, a relação entre o cristianismo e seus judeus nos séculos XIX e XX e sobre a questão dos desenhos de Maomé em 2005. Dialogando com outras áreas do conhecimento como a psicanálise, a sociologia e a história, a autora aponta o que seria um fio condutor em sua obra, "minha fascinação pelas situaçôes de crise" (Favret-Saada, 2009, p. 8), a partir das quais pode extrair severas críticas ao cientificismo ocidental. 


\section{Referências bibliográficas}

FAVRET-SAADA, Jeanne. Les mots, La mort, les sorts. Paris: Gallimard, 1977.

. "Ser afetado". Cadernos de Campo, n. 13, p. 155161, 2005 [1990].

$\therefore$ ISNART, Cyril. "En marge du dossier sur

l'empathie en anthropologie", Journal des anthropo- logues [en ligne], p. 114-115, 2008, mis en ligne le 01 décembre 2009 http://jda.revues.org/323

. Comment je suis devenu ethnologue. In: DHOQUOIS, Anne (org.). Paris : Le Cavalier Bleu, p. 7994, 2008.

GOLDMAN, Marcio. "Jeanne Favret-Saada, os afetos, a etnografia". Cadernos de Campo, n. 13: 149-153, 2005. 